\title{
Detection of IgM antibody against phase 1 flagelin for diagnosis of Salmonella paratyphi A infection
}

S. Korbsrisate, S. Sarasombath, P. Ekpo, N. Praaporn, M. Hossain, S. McKay

\begin{abstract}
Abstrak
Salmonella paratyphi A adalah bakteri patogen penyebab demam paratifoid. Teknik diagnostik laboratorium yang ada sekarang kurang memuaskan. Untuk memperbaiki diagnosis, telah dikonstruksi plasmid yang mengkode fase 1 gen flagelin $\mathrm{S}$. paratyphi $A$ pada nukleotida 460-890, pSK-8E. Protein rekombinan yang diekspresi dari pSK-8E digunakan untuk deteksi antibodi IgM pada indirect enzyme-linked immunosorbent assay. Telah dilakukan uji pada serum pasien-pasien dengan kultur darah positif terhadap:S. paratyphi $A$, S. typhi, bakteri negatif Gram dan positif Gram lain, demam berdarah dengue dan juga orang sehat sebagai kontrol. Sensitivitas, spesifisitas, efikasi, nilai prediksi positif dan negatif adalah sebagai berikut $56,8 \%, 98,8 \%, 92,0 \%, 90,6 \%$ dan $92,1 \%$. Sensitivitas dapat ditingkatkan menjadi 83,3\% apabila serum diperoleh pada hari 9 sampai 12 sejak timbulnya demam. Serum yang didapat lebih dini atau lebih lambat (14 hari) memberikan sensitivitas $34,8 \%$ dan 66,6\%. Hasil penelitian ini menunjukkan uji yang dikembangkan untuk deteksi antibodi IgM ini dapat digunakan untuk diagnosis infeksi S. paratyphi A apabila serum pasien diambil pada saat yang tepat.
\end{abstract}

\begin{abstract}
Salmonella paratyphi $A$ is a pathogenic bacteria that causes paratyphoid fever. The current laboratory diagnostic techniques available are unsatisfactory. To improve diagnosis, plasmid encoding S. paratyphi A phase I flagellin gene nucleotide positions $460-890$, $p S K-8 E$, has been constructed. The recombinant protein expressed from $p S K-8 E$ has been used to develop an indirect enzyme-linked immunosorbent assay for IgM antibody detection. Sera from patients with hemoculture positive for $\mathrm{S}$. paratyphi $A$, S. typhi, other grampositive and gram-negative bacteria, dengue hemorrhagic fever and the healthy control subjects have been tested. The calculated diagnostic sensitivity, specificity, efficacy, positive and negative predictive values are $56.8 \%, 98.8 \%, 92.0 \%, 90.6 \%, 92.1 \%$, respectively. The sensitivity is not satisfactory, therefore, data about the time taking the serum samples from the patients and the IgM levels are analysed. It has been shown that sensitivity of the test can be increased up to $83.3 \%$ if the serum have been obtained $9-12$ days after onset of fever. The serum obtained earlier or later (14days) gave only $34.8 \%$ and $66.6 \%$ sensitivity, respectively. This result suggests that the developed IgM antibody detection assay is powerful for diagnosis of $\mathrm{S}$. paratyphi $A$ infection when the serum samples have been taken at the appropriate time.
\end{abstract}

Department of Immunology, Faculty of Medicine, Siriraj Hospital, Bangkok 10700, Thailand. 